\title{
PENGEMBANGAN MEDIA KOMIK MATEMATIKA BERBASIS NILAI KARAKTER PADA MATERI TRIGONOMETRI DI KELAS X SMA NEGERI 1 INDRALAYA UTARA
}

\author{
Michael Amin Manalu ${ }^{1}$, Yusuf Hartono ${ }^{2}$, Nyimas Aisyah ${ }^{3}$ \\ ${ }^{1,2,3}$ Program Studi Pendidikan Matematika FKIP Universitas Sriwijaya \\ michaelaminm@gmail.com
}

\begin{abstract}
Abstrak
Penelitian ini bertujuan untuk: (1) Menghasilkan media komik matematika berbasis nilai karakter pada materi trigonometri di kelas X SMA yang valid dan praktis. (2) Mengetahui efek potensial yang muncul dari pengembangan media komik matematika berbasis nilai karakter pada materi trigonometri di kelas X SMA terhadap hasil tes siswa. Jenis penelitian yang digunakan adalah Development Research tipe Formative Evaluation. Subjek penelitian ini adalah siswa kelas X-1 SMA Negeri 1 Indralaya Utara tahun ajaran 2015/2016 yang berjumlah 30 siswa. Teknik pengumpulan data adalah dengan walkthrough, observasi, dan tes. Hasil dari penelitian ini adalah: (1) Penelitian ini telah menghasilkan media komik matematika berbasis nilai karakter pada materi trigonometri di kelas X SMA yang valid dan praktis. Validitas tergambar dari hasil penilaian validator dari segi konten, konstruk dan bahasa. Praktikalitas tergambar dari hasil ujicoba small group, dimana siswa dapat menggunakan media dengan baik sesuai perencanaan. (2) Media komik matematika berbasis nilai karakter dapat meningkatkan nilai karakter siswa. (3) Media komik matematika yang dikembangkan memiliki efek potensial yang positif terhadap hasil tes siswa, hal ini dapat dilihat bahwa siswa mencapai KKM $(\geq 2,51)$ sebesar $83 \%$ atau sebanyak 25 siswa.
\end{abstract}

Kata kunci : pengembangan, media, komik, nilai karakter, trigonometri

\begin{abstract}
This study aim to: (1) Produce media of math comics based on character values for trigonometry material on first grade (Class X) Senior High School which is valid and practical. (2) Determine the potential effects arise from development of mathematics comics media based on character values for trigonometry for first grade class toward student test result. The type of this research is Development Research, Formative Evaluation type. The subjects were student of Class X-1 of Public Senior High School No. 1 Indralaya Utara in academic year 2015/2016 totaling 30 students. Data collection techniques used is the walkthrough, observation and test. The results from this study are: (1) This research has produced a media of math comics based on character values for trigonometry material to first grade of senior high school which valid and practical. The validity drawn from the assessment result of validator in terms of content, construct, and language. Practicalities drawn from the results of a small group test where most student can well-use the media as planned. (2) Mathematics comics media based on character values can increase students character values. (3) Matematics comics media which is developed has a positive potential effect on students test results, it can be seen that the stundent achieving the Minimum Completeness Criteria \{Kriteria Ketuntasan Minimum $(\mathrm{KKM})\}$ of $\geq 2,51$ is amounted to $83 \%$ or as many as 25 students.
\end{abstract}

Keywords: Development, Media, Comics, Character Values, Trigonometry 


\section{PENDAHULUAN}

Menurut UU nomor 20 tahun 2003 (Depdiknas, 2003) tentang Sistem Pendidikan Nasional pada Pasal 3, disebutkan bahwa pendidikan nasional berfungsi mengembangkan kemampuan dan membentuk karakter serta peradaban bangsa yang bermartabat dalam rangka mencerdaskan kehidupan bangsa. Pendidikan nasional bertujuan untuk berkembangnya potensi peserta didik agar menjadi manusia yang beriman dan bertakwa kepada Tuhan Yang Maha Esa, berakhlak mulia, sehat, berilmu, cakap, kreatif, mandiri, dan menjadi warga negara yang demokratis serta bertanggung jawab. Sebagaimana dinyatakan pada UU nomor 20 tahun 2003 tentang Sistem Pendidikan Nasional Pasal 38 (Kemdikbud, 2013), kerangka dasar dan struktur kurikulum pendidikan dasar dan menengah ditetapkan oleh Pemerintah. Satuan pendidikan tetap harus merujuk pada kerangka dasar dan struktur kurikulum jika harus mengembangkan kurikulum sendiri. Ketentuan untuk merujuk pada kerangka dasar dan struktur kurikulum merupakan bagian dari quality assurance.

Menurut Sukemi, Staf Khusus Menteri Pendidikan dan Kebudayaan bidang Komunikasi dan Media, kurikulum 2013 adalah konsep pendidikan dan kebudayaan yang membangun karakter kejujuran bagi peserta didik. Dari sisi kompetensi pengetahuan dan keterampilan, peserta didik diajak mengembangkan kreatifitas, inovatif serta berpikir secara positif dalam rangka membangun generasi Indonesia yang kuat dan tangguh untuk masa depan (Kemdikbud, 2013)

Karakter menurut Pusat Bahasa Depdiknas adalah bawaan, hati, jiwa, kepribadian, budi pekerti, perilaku, personalitas, sifat, tabiat, tempramen, watak. Berkarakter adalah berkepribadian, berperilaku, bersifat, bertabiat, dan berwatak. Individu yang berkarakter baik atau unggul adalah seseorang yang berusaha melakukan hal-hal yang terbaik terhadap Tuhan Yang Maha Esa, dirinya, sesama, lingkungan, bangsa dan negara serta dunia internasional pada umumnya dengan mengoptimalkan potensi (pengetahuan) dirinya dan disertai dengan kesadaran, emosi dan motivasinya (perasaannya).

Lickona (2013) menjelaskan beberapa alasan perlunya pendidikan karakter, di antaranya: (1) Banyaknya generasi muda saling melukai karena lemahnya kesadaran pada nilai-nilai moral, (2) Memberikan nilai-nilai moral pada generasi muda merupakan salah satu fungsi peradaban yang paling utama, (3) Peran sekolah sebagai pendidik karakter menjadi semakin penting ketika banyak anak-anak memperoleh sedikit pengajaran moral dari orangtua, masyarakat, dan lembaga keagamaan, (4) masih adanya nilai-nilai moral yang secara universal masih diterima seperti perhatian, kepercayaan, rasa hormat, dan tanggungjawab, (5) Demokrasi memiliki kebutuhan khusus untuk pendidikan moral karena 
demokreasi merupakan peraturan dari, untuk dan oleh masyarakat, (6) Tidak ada sesuatu sebagai pendidikan bebas nilai. Sekolah mengajarkan pendidikan bebas nilai. Sekolah mengajarkan nilai-nilai setiap hari melalui desain ataupun tanpa desain, (7) Komitmen pada pendidikan karakter penting manakala kita mau dan terus menjadi guru yang baik, dan (8) Pendidikan karakter yang efektif membuat sekolah lebih beradab, peduli pada masyarakat, dan mengacu pada performasi akademik yang meningkat.

Trigonometri merupakan materi pelajaran matematika yang baru dikenal siswa pada saat sekolah menengah pertama, dan pemahaman trigonometri di sekolah menengah pertama masih sebatas konsep-konsep dasar yang masih dangkal. Perlu pemahaman yang mendasar tentang konsep-konsep trigonometri untuk memperdalamnya di sekolah menengah atas. Apabila bekal pemahaman siswa tentang konsep-konsep dasar trigonometri pada sekolah menengah pertama sudah tidak ada, maka siswa akan kesulitan untuk memahami materi trigonometri di sekolah menengah atas. Apabila siswa enggan utnuk mendiskusikan kesulitannya itu, maka siswa akan lebih sulit dalam memahami materi lanjutan trigonometri, sehingga memang perlu adanya media komik untuk mempermudah pemahaman siswa tentang materi trigonometri yang dirasa sulit.

Kemajuan teknologi yang berkembang pesat dalam pendidikan sangat berpengaruh terhadap proses pembelajaran. Proses pembelajaran perlu direncanakan, dilaksanakan, dinilai dan diawasi agar terlaksana secara efektif dan efisien. Adanya perkembangan teknologi dan informasi dalam dunia pendidikan seharusnya memberikan kemudahan terhadap proses pembelajaran. Hal ini dikarenakan dalam proses pembelajaran terjadi adanya penyampaian informasi, dimana dalam penyampaiannya dapat menggunakan alat-alat sebagai penyampai informasi atau materi yang menjadi tujuan instruksional. Alat-alat penyampai informasi inilah yang disebut dengan media pembelajaran. Dalam penelitian Elis Mediawati (2011:69) menjelaskan bahwa pengguna media pembelajaran pada tahap orientasi proses pembelajaran akan sangat membantu keefektifan proses pembelajaran dan penyampaian pesan pada materi pembelajaran. Di sisi lain media mampu membangkitkan motivasi dan minat siswa, media juga dapat membantu siswa meningkatkan pemahaman, menyajikan data yang menarik, terpercaya, memudahkan penafsiran data, dan memadatkan informasi. Maka perlu adanya pemilihan media pembelajaran yang sesuai dengan materi yang akan diajarkan, karena motivasi belajar siswa dan minat siswa dalam proses pembelajaran merupakan salah satu indikasi dari tersampaikannya informasi serta berhasilnya tujuan instruksional dalam proses pembelajaran. 
Oleh karena itu, perlu untuk menginterasikan nilai karakter dan teknologi ke dalam pembelajaran matematika. Integrasi itu dapat dilakukan dengan menggunakan media pembelajaran sebagai penyampaian informasi dengan berbasis nilai karakter. Media tersebut adalah komik matematika. Ahmad Rohani (1997:78) menyatakan bahwa "Komik adalah salah satu bentuk cerita bergambar, terdiri atas berbagai situasi cerita bersambung, kadang bersifat humor." Jadi media komik adalah alat bantu atau benda fisik yang berupa cerita dengan menggunakan rangkaian gambar tidak bergerak dan divisualisasikan dalam bentuk frame/kotak serta balon-balon ucapan yang lebih dari satu namun merupakan satu kesatuan cerita.

Media komik matematika adalah salah satu alat atau benda berupa cerita yang menggunakan rangkaian gambar tidak bergerak dan divisualisasikan dalam bentuk frame/kotak serta balon-balon ucapan dan simbol-simbol tertentu yang digunakan untuk menyampaikan pesan yang berisi permasalahan hitung matematika.

Novianti dan Syaichudin (2010:78) menyebutkan ada tujuh kelebihan media komik matematika antara lain: (1) peranan pokok dari buku komik dalam instruksional adalah kemampuannya dalam menciptakan minat peserta didik, (2) Membimbing minat baca yang menarik pada peserta didik, (3) Perwatakan lain dari komik harus dikenal agar kekuatan medium ini bisa dihayati, (4) Komik memusatkan perhatian di sekitar rakyat, (5) Cerita pada komik mengenai pribadi sehingga pembaca dapat segera mengidentifikasikan dirinya melalui perasaan serta tindakan dari perwatakan tokoh utamanya, (6) Ceritanya ringkas dan menarik perhatian, (7) Dilengkapi dengan aksi bahkan dalam lembaran surat kabar dan buku-buku, (8) Komik dibuat lebih hidup serta seolah dengan pemakaian warna-warna utama secara bebas.

Penanaman nilai-nilai karakter positif tersusun dalam komik melalui dialog, penggambaran tokoh dan game edukatif. Penelitian Nugraha, dkk (2013:62) menjelaskan bahwa tujuan pengembangan nilai karakter dalam komik yaitu agar peserta didik mampu memahami pesan-pesan positif yang terkandung di dalam komik serta mampu mengaplikasikan dalam kehidupan sehari-hari. Ditegaskan dalam penelitian Ijang Permana Sidik (2013:80) mengukur keefektifan media komik dalam meningkatkan hasil belajar siswa ranah kognitif, bahwa komik efektif untuk meningkatkan hasil belajar. Lebih lanjut penelitian Eka Arif Nugraha, dkk (2013:67) menjelaskan bahwa komik mampu untuk mengembangkan nilai karakter pada siswa, nilai karakter yang dikembangkan yaitu peduli lingkungan, peduli sosial, religius, rasa ingin tahu, disiplin dan kreatif. Pendidikan karakter berupa nilai karakter yang diterapkan dalam lingkungan pendidikan akan memiliki dampak langsung pada prestasi belajar. Meningkatnya hasil belajar efektif memicu pula menigkatnya hasil belajar kognitif. 
Hal ini sesuai dengan pendapat Juhartutik (2010) dalam Eka Arif Nugraha, dkk (2013:63) yang menyatakan bahwa meningkatnya hasil belajar efektif berupa karakter dapat meningkatkan hasil belajar kognitif siswa.

Dari hasil pengamatan oleh peneliti, penggunaan media komik matematika berbasis nilai karakter belum pernah dilaksanakan di sekolah menengah atas. Oleh karena itu, peneliti ingin mendesain komik matematika berbasis nilai karakter. Media komik yang dihasilkan memuat materi trigonometri.

Berdasarkan uraian di atas, peneliti tertarik untuk melakukan penelitian dengan judul "Pengembangan Media Komik Matematika Berbasis Nilai Karakter pada Materi Trigonometri di kelas X".

\section{METODE}

Dalam penelitian ini, peneliti menggunakan metode penelitian pengembangan atau development design research tipe formative research, yang bertujuan untuk menghasilkan media komik matematika berbasis nilai karakter pada materi trigonometri kelas X. Terdapat dua tahap dalam penelitian ini yaitu preliminary study ( tahap persiapan) dan formative study (tahap evaluasi dan revisi) (Tessmer, 1993). Penelitian dilakukan pada semester genap tahun akademik 2015/2016. Subjek penelitian adalah siswa kelas X SMA Negeri 1 Indralaya Utara.

Dalam penelitian ini, peneliti menggunakan metode penelitian pengembangan atau development design research tipe formative research. Terdapat dua tahap dalam penelitian ini yaitu preliminary study (tahap persiapan) dan formative study (tahap evaluasi dan revisi). Berikut langkah-langkah prosedur pengembangan materi disajikan dalam bentuk diagram alur.

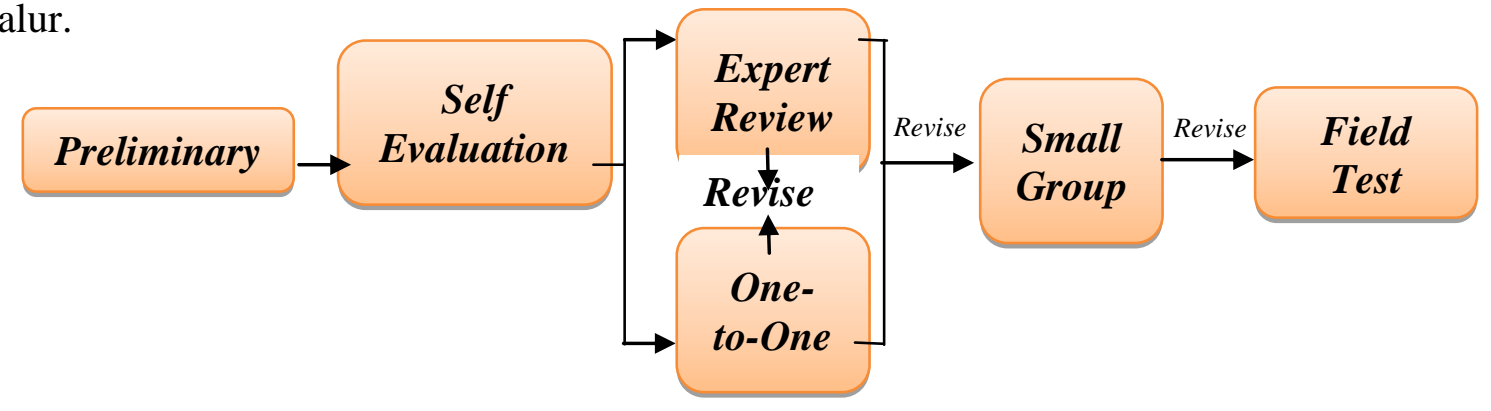

Gambar 1. Alur Desain Formative Evaluation (Tessmer, 1993; Zulkardi, 2006)

Teknik pengumpulan yang digunakan adalah walkthrough, observasi dan tes. Teknik walkthrough dilakukan pada tahap expert review. Walkthrough dilakukan untuk mengetahui kevalidan media pembelajaran dan soal tes dalam media kepada pakar. Lembar evaluasi pakar ditulis di lembar validasi. Lembar validasi akan diberikan kepada 4 validator. Validator 
melakukan validasi media pembelajaran mengenai kualitas isi dan tujuan, kualitas instruksional, kualitas bahasa dan kualitas teknis. Hasil validasi dari para pakar akan menjadi masukan untuk merevisi multimedia, Semua saran dan kritik ditulis di lembar validasi dan dicatat oleh peneliti, sebagai dasar untuk merevisi multimedia.

Menurut Mulyatiningsih (2012: 26) menjelaskan observasi merupakan metode pengumpulan data melalui pengamatan dan pencatatan perilaku subjek penelitian yang dilakukan secara sistematik. Observasi dilaksanakan untuk mengamati proses dan dampak yang muncul selama proses tindakan. Observasi digunakan untuk melihat aktivitas siswa dalam one-to-one dan small group.

Tes merupakan himpunan pertanyaan yang harus dijawab, harus ditanggapi, atau tugas yang harus dilaksanakan oleh orang yang dites. Tes digunakan untuk mengukur sejauh mana seorang siswa telah menguasai pelajaran yang disampaikan terutama meliputi aspek pengetahuan dan ketrampilan (Asep Jihad dan Abdul Haris, 2008: 67). Tes dilakukan dengan menjawab soal-soal yang disajikan dalam media pembelajaran yang dilakukan langsung pada tahap field test dengan memberikan soal-soal yang terdapat dalam media pembelajaran yang dikembangkan. Pemberian soal ini bertujuan untuk melihat efek potensial media pembelajaran yang disajikan terhadap hasil belajar siswa. Hasil belajar adalah kemampuan yang diperoleh anak setelah melalui kegiatan belajar (Abdurrahman, 1999). Pemberian tes dilakukan setelah penyajian media pembelajaran yang dilakukan pada hari berikutnya dalam rentang waktu yang dekat.

Data walkthrough berupa saran dan komentar pakar kemudian disajikan sebagai masukan untuk merevisi protoype I media komik matematika yang dikembangkan. Data observasi diperoleh langsung melalui one-to-one dan small group. Proses kegiatan dan respon siswa direkam dan didokumentasikan dalam bentuk foto dan video selama proses belajar. Analisis data observasi dilakukan secara deskriptif dengan melihat dan mengamati respon siswa terhadap penyajian media pembelajaran. Pengumpulan data observasi juga dilakukan oleh observer pada kelas yang disajikan subjek penelitian. Observasi ini dilakukan untuk melihat proses pelaksanaan pada saat penyajian media pembelajaran yang dikembangkan. Observasi ini juga dilakukan untuk melihat nilai karakter yang tertanam pada siswa. Adapun instrumen beserta rubrik penilaian yang akan diberikan yaitu sebagai berikut. 


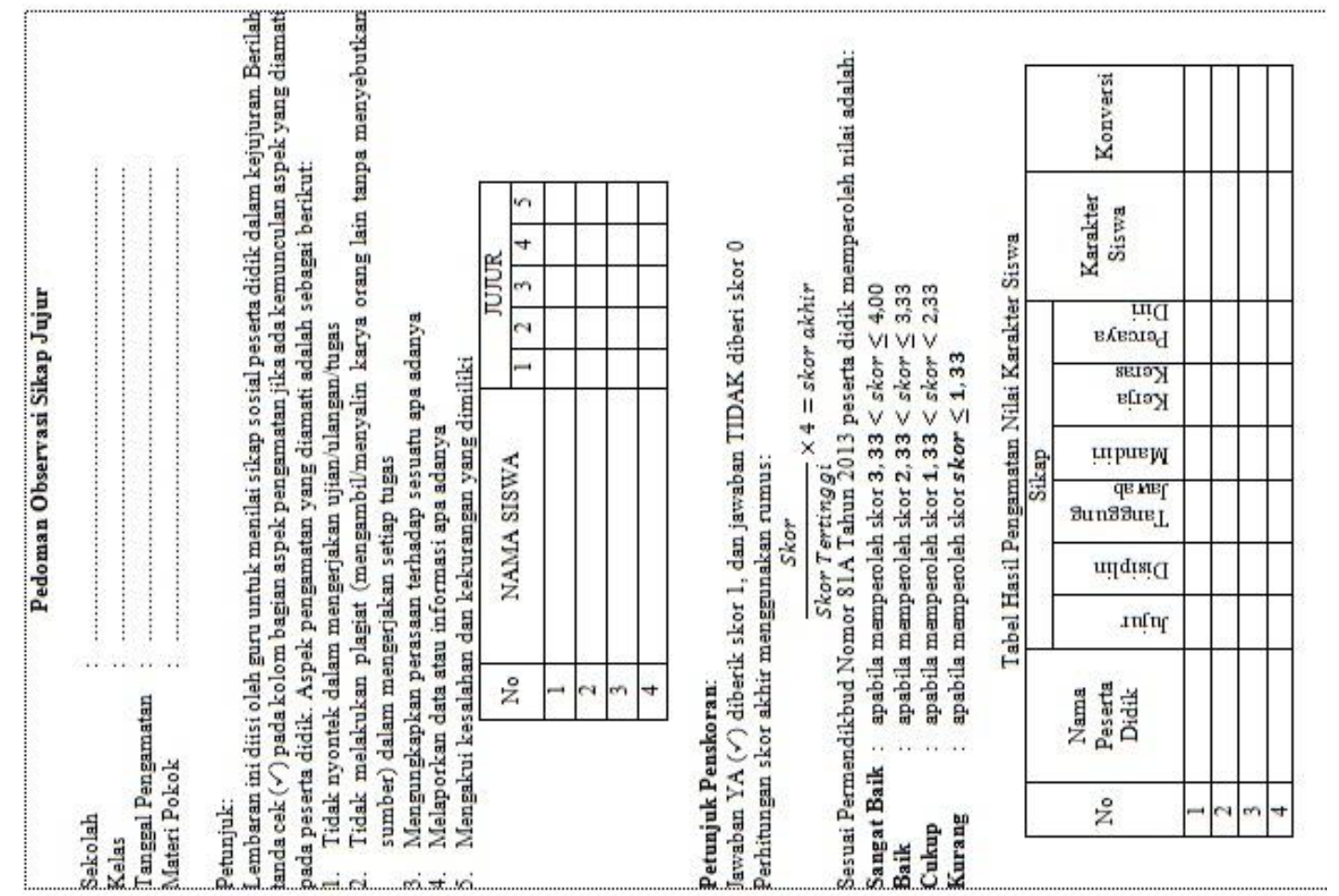

Gambar 2. Pedoman Obeservasi Sikap Jujur

Hasil belajar atau hasil tes siswa dapat diartikan sebagai kemampuan yang diperoleh oleh siswa melalui kegiatan belajar (Abdurrahman Mulyono, 1999). Data keefektifan media pembelajaran yang disajikan diperoleh dari skor yang didapatkan dari hasil pemahaman siswa. Indikator pemahaman media pembelajaran ini ditunjukkan dengan hasil evaluasi pengguna yang disediakan di dalam media pembelajaran yang langkah kerjanya dikerjakan di lembar jawaban yang telah disediakan di dalam media pembelajaran.

Adapun langkah-langkah yang dilakukan untuk menganalisis data hasil tes siswa adalah:

1. Memeriksa jawaban siswa

2. Memberikan skor dari hasil jawaban siswa sesuai pedoman penilaian sebagai berikut.

$$
\text { Konversi Nilai }=\frac{\text { Skor yang diperoleh }}{\text { Skor Maksimum }} \times 4
$$

Tabel 1. Konversi Nilai Ketuntasan Pencapaian Kompetensi Kurikulum 2013

\begin{tabular}{cc}
\hline Rentang Angka & Huruf \\
\hline $3,85-4,00$ & $\mathrm{~A}$ \\
\hline $3,51-3,84$ & $\mathrm{~A}-$ \\
\hline $3,18-3,50$ & $\mathrm{~B}+$ \\
\hline $2,85-3,17$ & $\mathrm{~B}$ \\
\hline $2,51-2,84$ & $\mathrm{~B}-$ \\
\hline $2,18-2,50$ & $\mathrm{C}+$ \\
\hline $1,85-2,17$ & $\mathrm{C}$ \\
\hline
\end{tabular}


3. Kriteria ketuntasan minimal hasil tes $\geq 2,51(\mathrm{~B}-)$

Media komik matematika berbasis nilai karakter dikatakan memberi efek potensial baik terhadap hasil belajar siswa jika hasil rata-rata ketuntasan tes siswa $\geq 75 \%$ siswa.

\section{HASIL DAN PEMBAHASAN}

Peneliti melakukan observasi di SMA Negeri 1 Indralaya Utara untuk mengetahui situasi dan kondisi kelas yang dijadikan objek penelitian. Observasi juga dilakukan untuk mendapatkan informasi tentang kegiatan pembelajaran matematika di kelas $\mathrm{X}$, jadwal matematika, dan waktu yang disepakati untuk penelitian. Dari hasil observasi disepakati kelas X-1 yang dijadikan subjek penelitian.

Sebelum melakukan penelitian, peneliti mempersiapkan media pembelajaran yang digunakan, dimulai dari tahap pengembangannya sampai media tersebut dinyatakan valid. Hal pertama yang dilakukan peneliti adalah mencari ide tentang materi trigonometri dengan cara membaca berbagai sumber buku pelajaran, yang kemudian digambarkan dalam bentuk komik di kertas ukuran A4. Setelah selesai membuat komik, peneliti meminta saran dan komentar terlebih dahulu kepada dosen matematika selaku validator untuk perbaikan media yang dibuat. Komik yang telah direvisi berdasarkan saran, ditunjukkan kembali kepada validator untuk dinilai apakah media sudah valid untuk digunakan.

Setelah media dinyatakan valid, peneliti melakukan tahap berikutnya yaitu one-to-one evaluation yang kemdian dilanjutkan dengan tahap small group. Saran yang didapatkan dari siswa pada tahap tersebut dijadikan acuan untuk perbaikan sebelum melakuakn penelitian pada tahap field test. Peneliti melakukan pengamatan serta peningkatan nilai karakter melalui media pembelajaran dan lembar observasi penilaian sikap sesaat dan sesudah pengembangan. Berdasarkan pengamatan yang dilakukan pada uji pengembangan melalui lembar observasi penilaian sikap sesaat dan sesudah pengembangan dapat dilihat pada gambar di bawah.

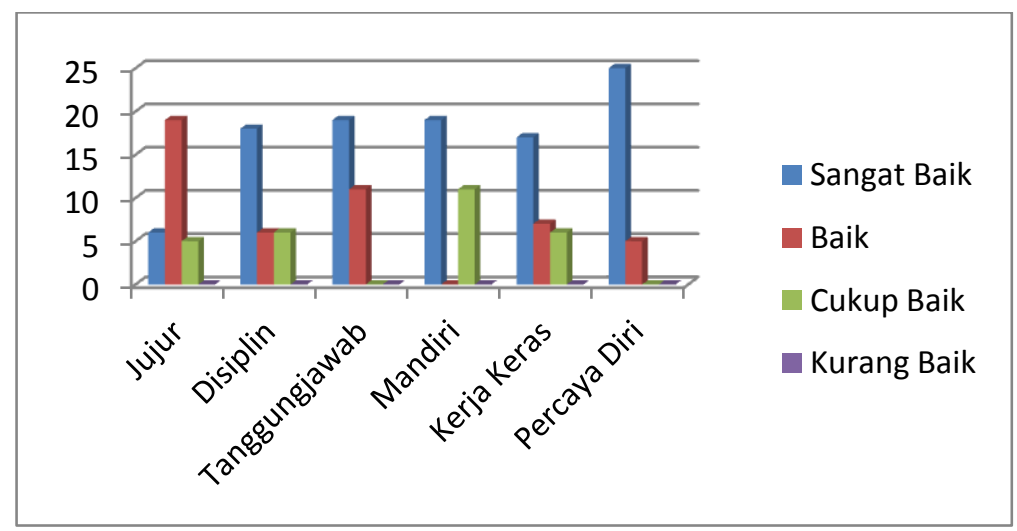

Gambar 3. Hasil observasi penilaian sikap sesaat dan sesudah pengembangan 
Dari gambar di atas dapat dilihat bahwa:

1. Kejujuran diperoleh nilai rata-rata sebesar 3,07 dengan predikat Baik. Rata-rata hasil nilai karakter jujur yang diperoleh siswa sudah termasuk kategori baik. Berdasarkan hasil uji coba yang dilakukan maka penilaian nilai karakter jujur sudah mulai terlihat. Pada saat siswa kesulitan dalam mengerjakan, merek tidak bertanya apa jawabannya tetapi bagaimana cara mengerjakan atau menjawabnya.

2. Kedisipplinan diperoleh nilai rata-rata sebesar 3,05 dengan predikat Baik. Rata-rata hasil nilai karakter disiplin yang diperoleh siswa sudah termasuk kategori baik. Berdasarkan hasil uji coba yang dilakukan maka penilaian nilai karakter disiplin sudah mulai terlihat. Hal ini dapat dilihat saat uji coba, siswa berusaha mengerjakan setiap soal dengan baik dan sesuai waktu yang sudah ditentukan.

3. Tanggung Jawab diperoleh nilai rata-rata sebesar 3,49 dengan predikat Sangat Baik. Rata-rata hasil nilai karakter tanggung jawab yang diperoleh siswa sudah termasuk kategori sangat baik. Berdasarkan hasil uji coba yang dilakukan maka penilaian nilai karakter tanggung jawab sudah mulai terlihat. Hal ini dapat dilihat saat siswa melaksanakan tugas individu dengan baik.

4. Mandiri diperoleh nilai rata-rata sebesar 3,27 dengan predikat Baik. Rata-rata hasil nilai karakter mandiri yang diperoleh siswa sudah termasuk kategori baik. Berdasarkan hasil uji coba yang dilakukan maka penilaian nilai karakter mandiri sudah mulai terlihat. Hal ini dapat dilihat pada saat uji coba, siswa antusias untuk mengerjakan soal dengan mandiri.

5. Kerja Keras diperoleh nilai rata-rata sebesar 3,25 dengan predikat Baik. Rata-rata hasil nilai karakter kerja keras yang diperoleh siswa sudah termasuk kategori baik. Berdasarkan hasil uji coba yang dilakukan maka penilaian nilai karakter kerja keras sudah mulai terlihat. Hal ini dapat terlihat ketika ada siswa yang belum bisa mengerjakan, mereka akan menghitung setiap soal dan mencoba untuk membaca kembali dengan kemampuan mereka untuk mencoba mengerjakan dengan penuh antusias.

6. Percaya Diri diperoleh nilai rata-rata sebesar 3,73 dengan predikat Sangat Baik. Rata-rata hasil nilai karakter percaya diri yang diperoleh siswa sudah termasuk kategori sangat baik. Berdasarkan hasil uji coba yang dilakukan maka penilaian nilai karakter percaya diri sudah mulai terlihat. Hal ini dapat dilihat pada saat uji coba, siswa antusias untuk mengerjakan soal dengan percaya diri. 
Adapun hasil belajar siswa pada pertemuan ketiga (tahap tes) dapat dilihat dalam tabel berikut.

Tabel 2. Analisis Hasil Belajar Siswa Kelas X-1

\begin{tabular}{ccc}
\hline Rentang Angka & Huruf & Jumlah \\
\hline $\mathbf{3 , 8 5}-\mathbf{4 , 0 0}$ & A & 1 \\
\hline $\mathbf{3 , 5 1}-\mathbf{3 , 8 4}$ & A- & 3 \\
\hline $\mathbf{3 , 1 8}-\mathbf{3 , 5 0}$ & B + & 8 \\
\hline $\mathbf{2 , 8 5}-\mathbf{3 , 1 7}$ & B & 8 \\
\hline $\mathbf{2 , 5 1}-\mathbf{2 , 8 4}$ & B- & 5 \\
\hline $\mathbf{2 , 1 8}-\mathbf{2 , 5 0}$ & C 5 & 3 \\
\hline $\mathbf{1 , 8 5}-\mathbf{2}, \mathbf{1 7}$ & $\mathrm{C}$ & 2 \\
\hline Jumlah & & 30 \\
\hline
\end{tabular}

Dari hasil tes yang dikerjakan siswa, diperoleh nilai rata-rata sebesar 3,14 dengan predikat Baik. Rata-rata hasil yang diperoleh siswa ini sudah termasuk kategori baik. Media komik matematika berbasis nilai karakter dikatakan mempunyai efek potensial terhadap hasil belajar siswa jika ketuntasan tes siswa $\geq 75 \%$. Hasil tes menunjukkan bahwa jumlah siswa yang mendapat nilai $\geq 2,51$ sebanyak 25 siswa (83\%). Ini berarti media komik matematika berbasis nilai karakter yang dikembangkan oleh peneliti telah memiliki efek potensial.

Adapun karakteristik media komik matematika berbasis nilai karakter pada materi trigonometri ini, yaitu peneliti mendesain komik dengan tampilan berwarna. Peneliti komik menyusun media komik berbentuk buku. Pada tampilan awal komik diberi cover agar tampilan media komik menarik. Dalam media komik terdapat tiga tokoh yang menyampaikan dialog yaitu Dina, Dani dan Angel. Pada halaman berikutnya dalam media komik terdapat kompetensi dasar, indikator, serta karakter yang dikembangkan.

Pada halaman berikutnya langsung membahas materi yaitu materi grafik fungsi sinus. Pada materi grafik fungsi sinus, diberikan langsung cara menggambar grafik fungsi sinus dimana harus membuat tabel grafik terlebih dahulu. Sehingga siswa dapat dengan mudah menggambar grafik fungsi sinus. Kemudian dilanjut dengan materi grafik fungsi kosinus dan menggambar grafik sinus dan kosinus dimana nilai $a \neq 1$.

Dalam media komik matematika diberikan dialog yang disusun sedemikian menarik, sehingga siswa dapat memahami materi dengan mudah. Dalam media komik matematika juga terdapat susunan dialog yang mengandung penanaman nilai karakter. Disamping siswa dapat memahami materi trigonometri, siswa juga mendapat nilai karakter dari susunan dialog yang terdapat dalam media komik matematika. Karakter yang ditanamkan pada media komik yaitu 
jujur, disiplin, tanggung jawab, mandiri, kerja keras, dan percaya diri dalam menyelesaikan berbagai permasalahan nyata terkait materi fungsi trigonometri.

Berdasarkan hasil belajar siswa dengan menggunakan media komik matematika berbasis nilai karakter diperoleh sebanyak 25 siswa (83\%) yang mendapatkan nilai $\geq 2,51$. Artinya, dapat dikatakan hasil belajar dengan menggunakan media komik matematika berbasis nilai karakter memberikan hasil belajar siswa yang termasuk baik. Hasil ini didukung Teori Crawford danWeiner (Cleaver, 2008) yang mengatakan banyak pendidik yang berhasil dalam mengajar ketika mereka menggunakan komik dalam pembelajaran.

Hasil belajar siswa juga sejalan dengan hasil observasi penilaian karakter siswa. Dimana siswa yang memiliki nilai karakter dengan kategori Sangat Baik (SB) berjumlah 19 siswa, Baik (B) berjumlah 6 siswa, dan Cukup (C) berjumlah 5 orang. Diperoleh persentase siswa yang nilai karakternya mulai terlihat yaitu 83, 33\%. Artinya, dapat dikatakan hasil penanaman nilai karakter dengan menggunakan media komik matematika berbasis nilai karakter menghasilkan siswa yang memiliki nilai karakter yang baik.

Secara keseluruhan hasil tes siswa memenuhi standar keberhasilan belajar sebesar $\geq$ $75 \%$ yaitu sebanyak 25 siswa (83\%) sesuai dengan hasil nilai karakter siswa yaitu 83,33\%. Media komik matematika berbasis nilai karakter yang telah dikembangkan peneliti termasuk dalam kategori baik dan memiliki efek potensial terhadap hasil belajar dan nilai karakter siswa. Namun di dalam kelas terdapat 5 siswa yang mendapatkan nilai paling rendah dibandingkan nilai-nilai siswa yang lain, hal ini terjadi karena siswa tidak menguasai kemampuan prasyarat, yaitu pengetahuan tentang perbandingan trigonometri sudut-sudut khusus dan perbandingan trigonometri dari sudut di semua kuadran, sehingga saat menyelesaikan grafik fungsi dengan menggunakan tabel, siswa mengalami kesulitan.

\section{SIMPULAN}

Produk penelitian ini adalah media komik matematika berbasis nilai karakter pada materi trigonometri kelas X SMA. Berdasarkan hasil penelitian dan pembahasan, diperoleh kesimpulan yaitu:

1. Kategori valid

a. Validitas dari aspek konten. Isi yang terdapat pada media komik matematika berbasis nilai karakter sesuai dengan kompetensi dasar yang akan dicapai, dengan indikator, (1) Mendeskripsikan konsep fungsi trigonometri (sinus, kosinus). (2) menganalisis konsep fungsi trigonometri (sinus, kosinus). (3) Menentukan hubungan nilai fungsi Trigonometri dan sudut-sudut istimewa. 
b. Validitas dari aspek konstruk: Media komik matematika berbasis nilai karakter dibuat sesuai dengan karakteristik komik sebagai media pembelajaran dan karakteristik penanaman karakter yang dapat membantu siswa dalam memahami konsep yang dipelajari.

c. Validitas dari aspek bahasa: Media komik matematika menggunakan bahasa yang sederhana dan mudah dipahami siswa.

2. Kategori praktis

Media dikatakan praktis terlihat dari hasil ujicoba pada tahap small group dimana siswa dapat menggunakan media dengan baik sesuai perencanaan.

3. Pengembangan media komik matematika berbasis nilai karakter dapat meningkatkan nilai karakter siswa, hal ini dapat diketahui dari aspek tiap nilai karakter pada siswa yang menunjukkan sudah mulai terlihat walaupun peningkatan yang dilakukan bermacammacam. Media komik matematika berbasis nilai karaker dapat meningkatkan nilai-nilai karakter yang ada pada setiap individu siswa yang meliputi aspek sebagai berikut:

a. Aspek jujur, pada uji pengembangan diperoleh nilai rata-rata karakter jujur siswa sebesar 3,07 dengan kategori baik dan nilai karakter jujur pada siswa mulai terlihat.

b. Aspek disiplin, pada uji pengembangan diperoleh nilai rata-rata karakter disiplin siswa sebesar 3,05 dengan kategori baik dan nilai karakter disiplin pada siswa mulai terlihat.

c. Aspek tanggung jawab, pada uji pengembangan diperoleh nilai rata-rata karakter tanggung jawab siswa sebesar 3,49 dengan kategori sangat baik dan nilai karakter tanggung jawab pada siswa mulai terlihat.

d. Aspek mandiri, pada uji pengembangan diperoleh nilai rata-rata karakter mandiri siswa sebesar 3,27 dengan kategori baik dan nilai karakter mandiri pada siswa mulai terlihat.

e. Aspek kerja keras, pada uji pengembangan diperoleh nilai rata-rata karakter kerja keras siswa sebesar 3,25 dengan kategori baik dan nilai karakter kerja keras pada siswa mulai terlihat.

f. Aspek percaya diri, pada uji pengembangan diperoleh nilai rata-rata karakter percaya diri siswa sebesar 3,73 dengan kategori sangat baik dan nilai karakter percaya diri pada siswa mulai terlihat.

4. Pengembangan media komik matematika berbasis nilai karakter yang ditunjukkan kepada siswa kelas X-1 SMA Negeri 1 Indralaya Utara memiliki efek potensial terhadap hasil 
belajar siswa dengan baik kategori baik. Ketuntasan yang dicapai siswa sebesar $83 \%$ dan telah memenuhi kriteria ketuntasan minimal yang ditentukan, yaitu $\geq 75 \%$.

\section{DAFTAR PUSTAKA}

Ahmad, R. (1997). Media Instruksional Edukatif. Jakarta: Rineka Cipta.

Amri, S dkk. (2011). Implementasi Pendidikan Karakter Dalam Pembelajaran. Jakarta: Prestasi Pustakarya.

Arsyad, A. (2011). Media Pembelajaran. Jakarta: Rajawali Pers.

Cleaver, S. (2008). Comics and Graphic Novels. Instructor, 117(6): 28-30.

Daryanto. (2011). Media Pembelajaran. Bandung: Nurani Sejahtera.

Depdiknas. (2003). Undang-undang RI No. 20 tahun 2003 tentang Sistem Pendidikan Nasional. Jakarta: Depdiknas.

Gumelar, M.S. (2011). Comic Making. Jakarta: PT Indeks.

Hudoyo, H. (2003). Pengembangan Kurikulum dan Pembelajaran Matematika. Malang: Universitas Negeri Malang.

Kemdikbud. (2013). Kerangka Dasar dan Struktur Kurikulum Sekolah Menengah Atas. Jakarta: Kemdikbud RI.

Kesuma, D dkk. (2011). Pendidikan Karakter: Kajian Teori dan Praktik di Sekolah. Bandung: Remaja Rosdakarya.

Lickona, T. (2013). Pendidikan Karakter: Panduan Lengkap Mendidik Siswa Menjadi Pintar dan Baik. Bandung: Penerbit Nusa Media.

Lie, A. (2005). Cooperative Learning: Mempraktikkan Cooperative Learning di Ruang-ruang Kelas. Jakarta: Grasindo.

Marsigit. (2003). Metodologi Pembelajaran Matematika. Yogyakarta: FMIPA UNY.

Mediawati, E. (2011). Pembelajaran Akuntansi Keuangan Melalui Media Komik untuk Meningkatkan Prestasi Mahasiswa. Jurnal Penelitian Pendidikan, 12(1).

Mulyatiningsih, E. (2012). Analisis Model-Model Pendidikan Karakter Untuk Usia AnakAnak, Remaja Dan Dewasa. Yogyakarta: UNY.

Mulyono, A. (1999). Pendidikan bagi Anak Berkesulitan Belajar. Jakarta: Rineka Cipta.

Muslich, M. (2008). KTSP Pembelajaran Berbasis Kompetensi Kontekstual. Jakarta: Bumi Aksara.

Muslich, M. (2011). Pendidikan Karakter, Menjawab Tantangan Krisis Multimensional. Jakarta: Bumi Aksara.

Narwanti, S. (2011). Pendidikan Karakter. Yogyakarta: Familia.

Novianti, R.D. \& Syaichudin, M. (2010). Pengembangan Media Komik Pembelajaran Matematika Untuk Meningkatkan Pemahaman Bentuk Soal Bab Pecahan Pada Siswa Kelas V SDN Ngembung. Jurnal Teknologi Pendidikan, 10(1): 78.

Nugraha, E. A dkk. (2013). Pembuatan Bahan Ajar Komik Sains Inkuiri Materi Benda untuk Mengembangkan Karakter Siswa Kelas IV SD. Unnes Physics Education Journal, 2(1).

Pusat Kurikulum. (2010). Buku Pedoman Pendidikan Budaya dan Karakter Bangsa. Jakarta: Pusat Kurikulum.

Sadiman, A. S., dkk. (2012). Media Pendidikan Pengertian, Pengembangan, dan Pemanfaatannya. Jakarta: PT Raja Grafindo Persada.

Saptono. (2011). Dimensi-Dimensi Pendidikan Karakter. Salatiga: Erlangga.

Sidik, I. P. (2013). Efektivitas Media Komik Digital Terhadap Peningkatan Hasil Belajar Siswa pada Mata Pelajaran Sejarah. Skripsi. Bandung: Universitas Pendidikan Indonesia. 
Soedjadi, R. (2000). Kiat Pendidikan Matematika di Indonesia: Konstatasi Keadaan Masa Kini Menuju Harapa Masa Depan. Jakarta: Dirjend Dikti Depdiknas.

Suherman, E. dkk. (2001). Strategi Pembelajaran Matematika Kontemporer. Bandung: Jica.

Sujarwo. (2008). Metode Pembelajaran Pendidikan Keaksaraan. Yogyakarta: Universitas Negeri Yogyakarta.

Tessmer, M. (1993). Planning and Conducting Formative Evaluations. London: Kogan Page. Trianto. (2010). Mendesain Model Pembelajaran Inovatif-Progresif. Jakarta: Kencana. Usman, M. U. (2000). Menjadi Guru Profesional. Bandung: Remaja Rosdakarya.

Zulkardi. (2006). Formative Evaluation: What, Why, When and How. http://www.reocities.org/zulkardi/books.html. Diakses tanggal 10 Januari 2016. 